\title{
FAKTOR-FAKTOR YANG MEMPENGARUHI MINAT MENJADI GURU EKONOMI
}

\author{
Selviani, S.Pd., M.Pd.E. ${ }^{1}$
}

\begin{abstract}
Abstrak
Penelitian ini bertujuan untuk mengungkapkan pengaruh kesiapan belajar, kepercayaan diri, fasilitas belajar, dan hasil belajar terhadap minat menjadi guru pada siswa IPS Sekolah Menengah Atas Negeri di Kota Tembilahan Kabupaten Indragiri Hilir.Jenis penelitian ini adalah penelitian deskriptif dan asosiatif.Populasi dalam penelitian ini sebanyak 216 siswa. Untuk menentukan sampel digunakan teknik Random Sampling dan diperoleh total sampel sebanyak 140 siswa. Tekhnik pengumpulan data dengan menggunakan kuesioner. Kuesioner yang akan disebarkan terlebih dahulu dilakukan uji coba dengan menguji validitas dan realibilitas. Tekhnik analisis data yang digunakan adalah analisis jalur dan uji hipotesis digunakan uji t. hasil penelitian menunjukkan bahwa: variabel kesiapan belajar, kepercayaan diri, fasilitas belajar, dan hasil belajar siswa memiliki pengaruh positif dan signifikan terhadap minat menjadi guru..
\end{abstract}

Keywords: kesiapan belajar, kepercayaan diri, fasilitas belajar, hasil belajar, danminat menjadi guru.

${ }^{1}$ DosenTetapEkonomiSyariah STAI AuliaurrasyidinTembilahan 


\section{A. Pendahuluan}

Syah mendefinisikan minat berarti kecenderungan dan kegairahan yang tinggi atau keinginan yang besar terhadap sesuatu ${ }^{2}$. Minat padadasarnya adalahpenerimaan akan suatu hubungan antara diri sendiri dengan sesuatu diluar diri. Semakin kuat atau dekat hubungant ersebut, semakin besar minat dalam diri seseorang. Minat menjadi guru adalah suatu faktor intern atau dalam diri individu yang mendorong dan mempengaruhi tingkah laku seseorang yang merasa tertarik dan ingin mewujudkan keinginannya menjadi seorang guru.

Sebelumnya, profesi guru memang dianggap kurang menarik minat bagi seseorang. Sekarang, profesi sebagai guru sangat diminati karena adanya program peningkatan kesejahteraan guru melalui program sertifikasi guru.Selain gaji pokok dan tunjangan umum sebagai pegawai negeri sipil (PNS), guru juga mendapatkan tunjangan profesi.

Tetapi pada kenyataannyab erdasarkan data yang ada, siswa memiliki minat yang rendah dalam duniapendidikan khususnya pada program studi pendidikan ekonomi. Hal ini dapat kita lihat dari tabelberiku tini:

Tabel 1

RekapitulasiPeminatMahasiswaBaru Program StudiPendidikanEkonomiUniversitasNegeri Padang Jalur SNMPTN

\begin{tabular}{|c|c|c|c|}
\hline No & TahunMasuk & Peminat & Persentase (\%) \\
\hline $\mathbf{1}$ & 2013 & 1.121 & 52 \\
\hline $\mathbf{2}$ & 2014 & 783 & 36 \\
\hline $\mathbf{3}$ & 2015 & 688 & 32 \\
\hline $\mathbf{4}$ & 2016 & 671 & 31 \\
\hline & Jumlah & $\mathbf{2 . 1 4 3}$ & \\
\hline
\end{tabular}

Sumber: Puskom UNP, 2018

${ }^{2}$ Syah Muhibbin, Psikologi Belajar, (Jakarta: RajawaliPers, 2012), hlm. 180. 
Tabel 2

Rekapitulasi Penerimaan Mahasiswa Baru Program Studi Pendidikan Ekonomi Universitas Negeri Padang Jalur SNMPTN

\begin{tabular}{|c|c|c|c|}
\hline No & TahunMasuk & Penerimaan & Persentase (\%) \\
\hline $\mathbf{1}$ & 2013 & 24 & 12 \\
\hline $\mathbf{2}$ & 2014 & 42 & 21 \\
\hline $\mathbf{3}$ & 2015 & 52 & 26 \\
\hline $\mathbf{4}$ & 2016 & 43 & 21 \\
\hline \multicolumn{2}{|c|}{ Jumlah } & $\mathbf{1 9 9}$ & \\
\hline
\end{tabular}

Sumber: Puskom UNP, 2018

Berdasarkan table diatas dapat disimpulkan bahwa setiap tahunnya minat mahasiswa dalam memasuki program studi pendidikan khususnya pada program studi pendidikan ekonomi mengalami fluktuasi.

Kurangnya minat menjadi guru dipengaruhi oleh beberapa faktor. Salah satunya adalah tingkat pemahaman atau hasil belajar. Hal inisesuaidenganpendapat Gore dalam Berry danDrielyaitu: "Argued for a focus on pedagogy in teacher education such that preservice teachers (PSTs) should "develop deep understandingof the complexities surrounding learning as well as strong skills for producing learning," to support their own students to "achieve high quality learning outcomes."

Sedangkan faktor yang mempengaruhi hasil belajar adalah kesiapan belajar.Slameto menyatakan kesiapan belajar adalah keseluruhan kondisi seseorang yang membuatnya siap untuk memberi respon atau jawaban di dalam cara tertentu terhadap suatu situasi ${ }^{4}$. Kesiapan belajar menjadi salah satu faktor yang cukup berpengaruh terhadaphasil belajar siswa. Seorang siswa yang telah memiliki kesiapan belajar yang baik sangat besar kemungkinannya untuk mendapatkan hasil belajar yang baik pula. Hal ini

${ }^{3}$ Berry Amanda \& Jan H. Van Driel, “Teaching About Teaching Science: AIMS, Strtategies, and Bacgrounds of Science Teacher Educators", (Journal of Teacher Education: SAGE, 2012), hlm. 117 hlm. 80

4Slameto, Belajar dan Faktor-faktor yang Mempengarubibya,(Jakarta: RinekaCipta), 2003, 
sesuai dengan penelitian yang dilakukan oleh Kaymak dan Horzum(2013) hasil penelitian menunjukkan adanya hubungan yang positif antara kesiapan belajar dengan interaksi dan keberhasilan pembelajaran ${ }^{5}$.

Faktor lain yang mempengaruhi hasil belajar adalah kepercayaan diri. Menurut Hakim, kepercayaan diri bisa dikatakan sebagai suatu keyakinan seseorang terhadap segala aspek kelebihan yang dimilikinya dan keyakinan tersebut membuatnya merasa mampu untuk bisa mencapai berbagai tujuan di hidupnya $^{6}$. Dalam proses belajar mengajardisekolahseorang siswa dituntut untuk mandiri dalam belajar, sehingga dalam proses belajar siswa harus aktif dalam mengungkapkan sebuah pendapat. Mereka yang pasif hanya akan diam dan menerima saja apa yang disampaikan oleh guru, sehingga sikap yang seperti itu akan sangat mempengaruhi tingkat pemahaman atau hasil belajar siswa disekolah. Hal ini sesuai dengan penelitian yang dilakukan oleh Shoemaker hasil penelitian menunjukkan bahwa ukuran keberhasilan pembelajaran adalah kepercayaan diri siswa. ${ }^{7}$

Selain kesiapan belajar dan kepercayaan diri, faktor yang mempengaruhi hasil belajar siswa adalah fasilitas belajar. Menurut Djamarah "fasilitas adalah segala sesuatu yang memudahkan anak didik". Fasilitas belajar yang mendukung kegiatan belajar peserta didik akan menyebabkan proses belajar mengajar menyenangkan dan memperoleh hasil belajar yang diharapkan ${ }^{8}$. Hal ini sesuai dengan penelitian yang dilakukan

${ }^{5}$ KaymakDemirZeliha\& Mehmet BarisHorzum, "Relationship Between Online Learning Readiness and Structure and Interaction of Online Learning Students",(Edam, 2013), hlm. 7

${ }^{6}$ Hakim T, Mengatasi Rasa Tidak Percaya Diri, (Jakarta: Puspa Swara, 2005), hlm. 6

${ }^{7}$ Shoemaker A-Candice, "Student Confidence as a Measure of Learning in an Undergraduate Principles of Horticultural Science Course",(Kansas State University, 2010), hlm. 11 hlm. 46

${ }^{8}$ Syaiful Bahri Djamarah, Strategi Belajar Mengajar, (Jakarta: PT Rineka Cipta, 2006), 
Schneider (2002) hasil penelitian menunjukkan bahwaf asilitas belajar mempengaruhi hasil belajarak ademik. ${ }^{9}$

Pada penelitian ini kesiapan belajar, kepercayaan diri, dan fasilitas belajar akan menjadi variabel eksogen, hasil belajar akan menjadi variabel intervening dan minat menjadi guru menjadi variabel endogen. Tujuan penelitian ini adalah untuk mendeskripsikan pengaruh kesiapan belajar, kepercayaan diri, dan fasilitas belajar terhadap hasil belajar siswa IPS SMA Negeri di Kota Tembilahan, Kabupaten Indragiri Hilir, Riau dan akan mendeskripsikan pengaruh kesiapan belajar, kepercayaan diri,fasilitas belajar, dan hasil belajar terhadap minat untuk menjadi guru siswa IPSSMA Negeri di Kota Tembilahan, Kabupaten Indragiri Hilir, Riau. Dan kemudian, manfaat penelitian bahwa hasil penelitian akan memberikan masukan untuk mengembangkan dunia pendidikan dan akan digunakan sebagai referensi untuk penelitian lebih lanjut.

\section{B. Metode Penelitian}

Jenis penelitian ini adalah penelitian deskriptif kuantitatif. Penelitian ini dilakukan pada siswa IPS sekolah menengah atas negeri di kota Tembilahan Kabupaten Indragiri Hilir. Populasi dalam penelitian ini sebanyak 216 siswa.Teknik pengambilan sampel yang digunakan adalah Random Sampling sehingga diperoleh sampel sebanyak 140 siswa.Instrumen penelitian yang digunakan berupa kuesioner.Analisis data dalam penelitian ini menggunakan Analisis Jalur (Path Analysis) dengan menggunakan program SPSS 16.00 for windows.

${ }^{9}$ Mark Schnaider, "Do School Facilities Affect Academic Outcomes", (Eric, 2002), hlm. 2 


\section{Hasil dan Pembahasan}

Penelitian ini membahas tentang pengaruh kesiapan belajar, kepercayaan diri, fasilitas belajar, dan hasil belajar terhadap minat menjadi guru dengan menggunakan analisis jalur.Untuk melakukan analisa jalur (path analysis) maka struktur hubungan pada diagram jalur dibagi menjadi dua model yaitu analisis koefisien jalur model I dan analisis koefisien jalur model II.Analisis koefisien jalur model I akan membahas pengaruh variabel Kesiapan Belajar (X.1), Kepercayaaan Diri (X.2), Fasilitas Belajar (X.3) terhadap Hasil Belajar Ekonomi Siswa (X.4). Sedangkan analisis koefisien jalur model 2 akan membahas pengaruh variabel Kesiapan Belajar (X.1), Kepercayaaan Diri (X.2), Fasilitas Belajar (X.3), Hasil Belajar Ekonomi Siswa (X.4) terhadap Minat Menjadi Guru Ekonomi (Y).

\section{Analisis Koefisien Jalur Model I}

Tabel 1

Koefisien Jalur KesiapanBelajar (X.1), KepercayaaanDiri (X.2), FasilitasBelajar (X.3) terhadapHasilBelajarEkonomiSiswa

\begin{tabular}{|c|c|c|c|c|c|}
\hline Pengaruhantarvariable & $\begin{array}{l}\text { Koefisien } \\
\text { Jalur } \\
\text { (Beta) }\end{array}$ & $\begin{array}{l}\text { Nilai } \\
\text { Sig. }\end{array}$ & $\begin{array}{l}\text { HasilPenguji } \\
\text { an }\end{array}$ & $\begin{array}{l}\text { KoefisienD } \\
\text { eterminasi }\end{array}$ & $\begin{array}{l}\text { Koefisie } \\
\text { nVariab } \\
\text { el Lain }\end{array}$ \\
\hline X1 terhadap X4 & 0,208 & 0,007 & $\begin{array}{l}\text { Berpengaruh } \\
\text { signifikan }\end{array}$ & \multirow{3}{*}{$\begin{array}{l}0,530 \\
= \\
53,0 \%\end{array}$} & \multirow{3}{*}{0,6855} \\
\hline $\mathrm{X} 2$ terhadap X4 & 0,365 & 0,000 & $\begin{array}{l}\text { Berpengaruh } \\
\text { signifikan }\end{array}$ & & \\
\hline X3 terhadap X4 & 0,289 & 0,000 & $\begin{array}{l}\text { Berpengaruh } \\
\text { signifikan }\end{array}$ & & \\
\hline
\end{tabular}

Berdasarkan hasil nilai tersebut diperoleh diagram jalur untuk model jalur I yang digambarkan sebagai berikut: 


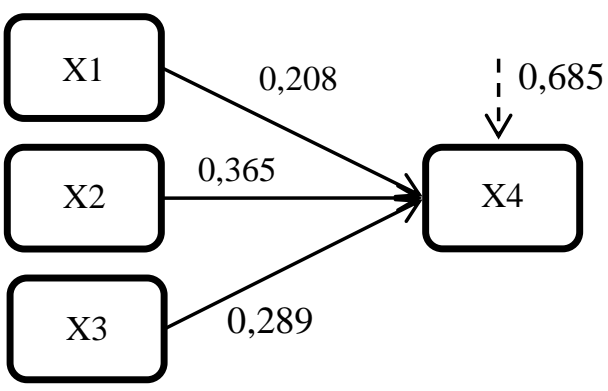

Dengan demikian dapat diperoleh persamaan struktural untuk model jalur I sebagai berikut:

$$
\begin{aligned}
& Y=p y X 1+p y X 2+\varepsilon 1 \\
& Y=0,208+0,365+0,289+0,685 \\
& \text { Dimana } \mathrm{R}^{2}=0,530
\end{aligned}
$$

Berdasarkan persamaan struktural model jalur I, dapat diartikan bahwa:

1) Hasil Belajar (X.4) dipengaruhi oleh KesiapanBelajar (X.1), Kepercayaan Diri (X.2), dan Fasilitas Belajar (X.3) secara simultan dan signifikan sebesar $53 \%$ dan sisanya $47 \%$ dipengaruhi oleh variabel-variabel lain di luar penelitiani ni

2) Semakin baik Kesiapan Belajar (X.1) yang ada pada siswa, maka Hasil Belajar (X.4) juga akans emakin tinggi. Begitu pula sebaliknya, semakin buruk kesiapan belajar (X.1) yang ada pada siswa maka hasil belajar (X.4) akan semakin rendah.

3) Semakin baik Kepercayaan Diri (X.2) yang ada pada siswa, maka hasil belajar (X.4) juga akan semakin tinggi. Begitu pula sebaliknya, semakin buruk kepercayaan diri (X.2) maka hasil belajar siswa akan semakin rendah.

4) Semakin baik Fasilitas Belajar (X.3) yang diterima siswa maka hasil belajar (X.4) juga akan semakin tinggi. Begitu pula sebaliknya, 
semakin buruk fasilitas belajar (X.3) yang diterima siswa maka hasil belajar (X.4) akan semakin rendah.

\section{AnalisisKoefisienJalur Model II}

Tabel 2

Koefisien Jalur Kesiapan Belajar (X.1), Kepercayaaan Diri (X.2), Fasilitas Belajar (X.3) Hasil Belajar Ekonomi (X4) Terhadap Minat Menjadi Guru

Ekonomi (Y)

\begin{tabular}{|c|c|c|c|c|c|}
\hline $\begin{array}{l}\text { Pengaruhant } \\
\text { arvariable }\end{array}$ & $\begin{array}{l}\text { Koefisi } \\
\text { enJalur } \\
\text { (Beta) }\end{array}$ & $\begin{array}{l}\text { Nila } \\
\text { iSig. }\end{array}$ & $\begin{array}{l}\text { HasilPenguj } \\
\text { ian }\end{array}$ & $\begin{array}{l}\text { KoefisienD } \\
\text { eterminasi }\end{array}$ & $\begin{array}{l}\text { Koefisien } \\
\text { Variabel } \\
\text { Lain }\end{array}$ \\
\hline $\begin{array}{l}\text { X1 terhadap } \\
\text { Y }\end{array}$ & 0,359 & $\begin{array}{l}0,00 \\
0\end{array}$ & $\begin{array}{l}\text { Berpengaru } \\
\text { hsignifikan }\end{array}$ & \multirow{4}{*}{$\begin{array}{l}0,644 \\
= \\
64,4 \%\end{array}$} & \multirow{4}{*}{0,596} \\
\hline $\begin{array}{l}\text { X2 terhadap } \\
\text { Y }\end{array}$ & 0,197 & $\begin{array}{l}0,00 \\
7\end{array}$ & $\begin{array}{l}\text { Berpengaru } \\
\text { hsignifikan }\end{array}$ & & \\
\hline $\begin{array}{l}\text { X3 terhadap } \\
\text { Y }\end{array}$ & 0,189 & $\begin{array}{l}0,00 \\
7\end{array}$ & $\begin{array}{l}\text { Berpengaru } \\
\text { hsignifikan }\end{array}$ & & \\
\hline $\begin{array}{l}\text { X4 terhadap } \\
\text { Y }\end{array}$ & 0,220 & $\begin{array}{l}0,00 \\
4\end{array}$ & $\begin{array}{l}\text { Berpengaru } \\
\text { hsignifikan }\end{array}$ & & \\
\hline
\end{tabular}

Berdasarkan hasil nilai tersebut, dapat diperoleh diagram jalur untuk model II yang digambarkan sebagai berikut:

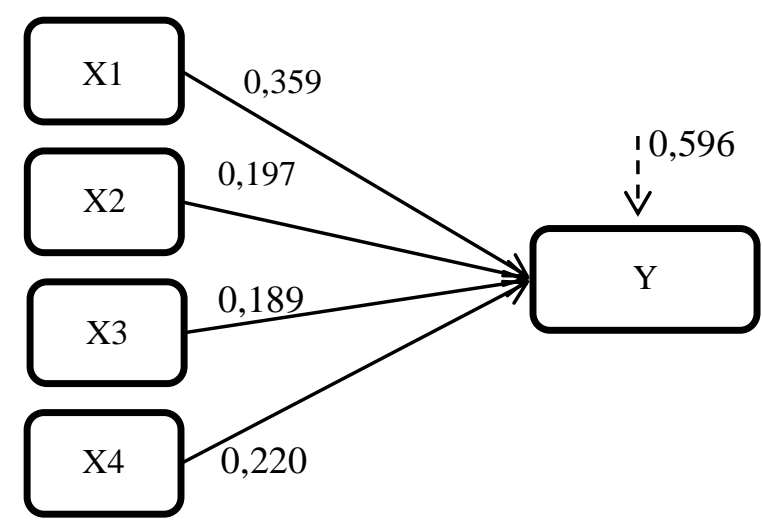

Dengan demikian dapat diperoleh persamaan struktural untuk model II sebagai berikut: 


$$
\begin{aligned}
& Y=p Y X 1+p Y X 2+p Y X 3+p Y X 4+\varepsilon 2 \\
& Y=0,359+0,197+0,189+0,220+0,596 \\
& \text { Dimana } \mathrm{R}^{2} \text { adalah } 0,644
\end{aligned}
$$

Berdasarkan persamaan struktural pada model II dapat diartikan bahwa:

1) Minat Menjadi Guru Ekonomi (Y) dipengaruhi oleh Kesiapan Belajar (X.1), Kepercayaan Diri (X.2), dan FasilitasBelajar (X.3) dan Hasil Belajar Ekonomi (X.4) secara simultan dan signifikan sebesar $64,4 \%$ dan sisanya $36,6 \%$ dipengaruhi oleh variabel-variabel lain di luar penelitian ini

2) Semakin baik Kesiapan Belajar (X.1) yang ada pada siswa, maka Minat Menjadi Guru Ekonomi (Y) juga akan semakin tinggi. Begitu pula sebaliknya, semakin buruk kesiapan belajar (X.1) yang ada pada siswa maka Minat Menjadi Guru Ekonomi (Y) akan semakin rendah.

3) Semakin baik Kepercayaan Diri (X.2) yang ada pada siswa, maka Minat Menjadi Guru Ekonomi (Y) juga akan semakin tinggi. Begitu pula sebaliknya, semakin buruk kepercayaan diri (X.2) maka Minat Menjadi Guru Ekonomi (Y) akan semakin rendah.

4) Semakin baik Fasilitas Belajar (X.3) yang diterima siswa maka Minat Menjadi Guru Ekonomi (Y) juga akan semakin tinggi. Begitu pula sebaliknya, semakin buruk fasilitas belajar (X.3) yang diterima siswa maka Minat Menjadi Guru Ekonomi (Y) akan semakin rendah.

5) Semakin baik Hasil Belajar Ekonomi (X.4) yang diperoleh siswa maka Minat Menjadi Guru Ekonomi (Y) juga akan semakin tinggi. Begitu pula sebaliknya, semakin buruk Hasil Belajar Ekonomi (X.4) yang diperoleh siswa maka Minat Menjadi Guru Ekonomi (Y) akan semakin rendah. 


\section{PEMBAHASAN:}

1. Pengaruh Kesiapan Belajar Terhadap Hasil Belajar Ekonomi

Berdasarkan hasil analisis jalur yang telah dilakukan, diperoleh nilai koefisien pengaruh langsung kesiapan belajar terhadap hasil belajar ekonomi (pengaruh total) sebesar 20,8\%. Uji hipotesis menunjukkan bahwa kesiapan belajar berpengaruh positif dan signifikan terhadap hasil belajar ekonomi pada siswa SMA kelas XI IPS di Tembilahan. Dapat diartikan bahwa Semakin baik Kesiapan Belajar yang ada pada siswa, maka Hasil Belajar juga akan semakin tinggi. Begitu pula sebaliknya, semakin buruk kesiapan belajar yang ada pada siswa maka hasil belajar akan semakin rendah.

Temuan ini sesuai dengan pendapat Mulyani bahwa kesiapan belajar behubungan pada tingkat koefisien korelasi cukup kuat antara kesiapan belajar siswa dengan prestasi belajar. ${ }^{10}$ Dari hasil penelitian ini terlihat bahwa Kesiapan merupakan faktor penting penentuan keberhasilan dalam belajar. Kesiapan ini perlu diperhatikan dalam proses belajar, karena jika siswa belajar sudah ada kesiapan, maka prestasi belajarnya akan lebih baik.

2. Pengaruh Kesiapan Belajar Terhadap Minat menjadi Guru Ekonomi

Berdasarkan hasil analisis jalur yang telah dilakukan, diperoleh nilai koefisien pengaruh langsung kesiapan belajar terhadap minat menjadi guru sebesar $35,9 \%$ dan nilai koefisien pengaruh tidak langsung sebesar 4, 57\%.Uji hipotesis menunjukkan bahwa kesiapan belajar berpengaruh positif dan signifikan terhadap minat menjadi guru ekonomi pada siswa SMA kelas XI IPS di tembilahan. Dapat diartikan bahwa Semakin baik kesiapan belajar yang ada pada siswa, maka minat menjadi guru ekonomi juga akan semakin tinggi. Begitu pula

${ }^{10}$ DessyMulyani, "HubunganKesiapanBelajarSiswadenganPrestasiBelajar", (JurnalIlmiahKonseling: Vol 2 No 1, 2013)hlm. 7 
sebaliknya, semakin buruk kesiapan belajar yang ada pada siswa maka Minat Menjadi Guru Ekonomi akan semakin rendah.

Temuan ini sejalan dengan pendapat Ni'mahdkk, bahwa minat profesi guru berpengaruh terhadap kesiapan menjadi guru ${ }^{11}$. Hal ini senada dengan pendapat Slameto yang menyatakan bahwa,"kesiapan mencakup tiga aspek salah satunya adalah keterampilan, pengetahuan dan pengertian lain yang telah dipelajari”. ${ }^{12}$

3. Pengaruh Kepercayaan Diri Terhadap Hasil Belajar Ekonomi

Berdasarkan hasil analisis jalur yang telah dilakukan, diperoleh nilai koefisien pengaruh langsung kepercayaan diri terhadap hasil belajar ekonomi (pengaruh total) sebesar 36,5\%. Uji hipotesis menunjukkan bahwa kepercayaan diri berpengaruh positif dan signifikan terhadap hasil belajar ekonomi pada siswa SMA kelas XI IPS di Tembilahan. Dapat diartikan bahwa Semakin baik kepercayaan diri yang ada pada siswa, maka hasil belajar juga akan semakin tinggi. Begitu pula sebaliknya, semakin buruk kepercayaan diri maka hasil belajar siswa akan semakin rendah.

Temuan ini sejalan dengan pendapat Jananti, dkk (2014) bahwa terdapat pengaruh kepercayaan terhadap hasil belajar ekonomi. ${ }^{13}$ Hasil penelitian tersebut menunjukkan bahwa semakin tinggi kepercayaan diri akan semakin baik pula hasil belajar ekonomi siswa. Begitu pula sebaliknya, apabila semakin rendah kepercayaan diri siswa maka akan semakin rendah pula hasil belajar siswa. Diharapkan siswa mulai berani

${ }^{11}$ Fahmi Ni'mah, "Pengaruh Minat Profesi Guru, Locus of Control Internal, Peran Guru Pamong, dan Prestasi Belajar terhadap kesiapan Mahasiswa Menjadi Guru pada jurusan Pendidikan Ekonomi Fakultas Ekonomi Universitas Negeri Semarang", (Jurnal Pendidikan Ekonomi ,Vol. 03: Universitas Negeri Semarang: 2014), hlm 8

${ }^{12}$ Ibid, hlm 113

${ }^{13}$ Jananti Nooriza \& Tarmudji Tarsis, "Pengaruh Kepercayaan Diri, Budaya Lokal dan pendidikan Agama terhadap Hasil Belajar Mata Pelajaran Ekonomi Siswa kelas XI IPS SMAN 1 Demak Tahun Ajaran 2013/2014”, (Economic Education Analysis Journal: Universitas Negeri Semarang, 2014), hlm 7 
untuk bertanya ketika mengikuti kegiatan belajar mengajar dan terjadi interaksi antara siswa dengan guru dan siswa dengan siswa.Sehingga mampu meningkatkan hasil belajar akuntansi siswa.

4. Pengaruh Kepercayaan Diri Terhadap Minat Menjadi Guru Ekonomi

Berdasarkan hasil analisis jalur yang telah dilakukan, diperoleh nilai koefisien pengaruh langsung kepercayaan diri terhadap minat menjadi guru ekonomi sebesar 19,7\%. dan nilai koefisien pengaruh tidak langsung sebesar 8,03\%. Uji hipotesis menunjukkan bahwa kepercayaan diri berpengaruh positif dan signifikan terhadap minat menjadi guru ekonomi pada siswa SMA kelas XI IPS di Tembilahan. Dapat diartikan bahwa semakin baik kepercayaan diri yang ada pada siswa, maka minat menjadi guru ekonomi juga akan semakin tinggi. Begitu pula sebaliknya, semakin buruk kepercayaan diri maka minat menjadi guru ekonomi (Y) akan semakin rendah.

Hal ini sesuai dengan pendapat Hakim, rasa percaya diri yang ada dalam diri seseorang akan memberikan keyakinan terhadap segala aspek kelebihan yang dimilikinya dan keyakinan tersebut membuatnya mampu untuk bias mencapai tujuan dalam hidupnya. ${ }^{14}$

5. Pengaruh Fasilitas Belajar Terhadap Hasil Belajar Ekonomi

Berdasarkan hasil analisis jalur yang telah dilakukan, diperoleh nilai koefisien pengaruh langsung kepercayaan diri terhadap minat menjadi guru ekonomi (pengaruh total) sebesar 28,9\%. Uji hipotesis menunjukkan bahwa fasilitas belajar berpengaruh positif dan signifikan terhadap hasil belajar ekonomi pada siswa SMA kelas XI IPS di Tembilahan. Dapat diartikan bahwa Semakin baik fasilitas belajar yang diterima siswa maka hasil belajar juga akan semakin tinggi. 
Begitu pula sebaliknya, semakin buruk fasilitas belajar yang diterima siswa maka hasil belajar akan semakin rendah.

Hal ini sesuai dengan pendapat Bangun, bahwa terdapat hubungan yang positif dan signifikan antara kelengkapan fasilitas belajar dengan prestasi belajar ekonomi. Dari hasil penelitian dapat disimpulkan bahwa jika kelengkapan fasilitas belajar dapat terpenuhi dengan baik, maka akan membantu kegiatan belajar siswa, sehingga dapat meningkatkan prestasi belajar siswa ${ }^{15}$.

6. Pengaruh Fasilitas Belajar Terhadap Minat Menjadi Guru Ekonomi

Berdasarkan hasil analisis jalur yang telah dilakukan, diperoleh nilai koefisien pengaruh langsung kepercayaan diri terhadap minat menjadi guru ekonomi (pengaruh total) sebesar 28,9\%. Berdasarkan tingkat capaian responden untuk variabel kepercayaan diri terlihat bahwa ruanganbelajar yang memilikisirkulasiudara yang baikmerupakan tingkat capaian responden tertinggi yaitu $88,00 \%$ yang berada pada kategori baik. Sedangkan memiliki alat tulis yang lengkap merupakan tingkat capaian responden terendah yaitu $82,86 \%$ yang berada pada kategori baik.Uji hipotesis menunjukkan bahwa fasilitas belajar berpengaruh positif dan signifikan terhadap hasil belajar ekonomi pada siswa SMA kelas XI IPS di Tembilahan. Dapat diartikan bahwa Semakin baik fasilitas belajar yang diterima siswa maka hasil belajar juga akan semakin tinggi. Begitu pula sebaliknya, semakin buruk fasilitas belajar yang diterima siswa maka hasil belajar akan semakin rendah.

Hurlock menyatakanminat mengandung unsur-unsur kognisi (mengenal), emosi (perasaan), dan Konasi (kehendak). Unsur kognisi

\footnotetext{
${ }^{15}$ Darwin Bangun, "Hubungan Persepsi Siswa Tentang Perhatian Orang Tua, Kelengkapan Fasilitas Belajar, dan Penggunaan Waktu Belajar di Rumah dengan Prestasi Belajar Ekonomi”, (Jurnal Ekonomi dan pendidikan: Vol 5, No 1, 2008) hlm 11 
(mengenal) dapat diperoleh dari proses pembelajaran yang ditunjang oleh fasilitas-fasilitas belajar yang memadai. ${ }^{16}$

7. Pengaruh Hasil Belajar Terhadap Minat Menjadi Guru Ekonomi

Berdasarkan hasil analisis jalur yang telah dilakukan, diperoleh nilai koefisien pengaruh langsung hasil belajar terhadap minat menjadi guru ekonomi sebesar 22\%.Uji hipotesis menunjukkan bahwa hasil belajar berpengaruh positif dan signifikan terhadap minat menjadi guru ekonomi pada siswa SMA kelas XI IPS di Tembilahan. Dapat diartikan bahwa Semakin baik hasil belajar ekonomi yang diperoleh siswa maka minat menjadi guru ekonomi juga akan semakin tinggi. Begitu pula sebaliknya, semakin buruk hasil belajar ekonomi yang diperoleh siswa maka minat menjadi guru ekonomi akan semakin rendah.

Temuan ini sesuai dengan pendapat Diyantini, dkk (2016) hasil penelitian menunjukkan bahwa prestasi belajar berpengaruh positif dan signifikan terhadap minat menjadi guru pada mahasiswa Prodi Pendidikan Akuntansi FKIP UNS. ${ }^{17}$

\section{Kesimpulan}

Berdasarkan hasil penelitian dan pembahasan dapat ditarik kesimpulan bahwakesiapan belajar, kepercayaan diri, fasilitas belajar, dan hasil belajar baik secara langsung maupun tidak langsung dapat memberikan pengaruh terhadap minat menjadi guru. Artinya dengan meningkatkan kesiapan belajar, meningatkan kepercayaan diri, memperhatikan fasilitas

${ }^{16}$ Elizabeth Hurlock, Perkembangan Anak Jilid 2: Alih Bahasa Meitasasi Tjandrasa, (Jakarta: Erlangga, 2010) hlm. 117

${ }^{17}$ Santosa Sigit Diyantini \& Dini Octaria, "Pengaruh Prestasi Belajar dan Persepsi Mahasiswa Tentang Kesejahteraan Guru terhadap Minat Menjadi Guru pada Mahasiswa Prodi Pendidikan Ekonomi Akuntansi FKIP UNS”, (Jurnal Tata Arta, Vol 2 No 2: UNS, 2016) hlm 10 
belajar dirumah dan disekolah, sertameningkatkan hasil belajar ekonomi, dapat memperkuat minat untuk menjadi guru ekonomi sehingga dapat memaksimalkan potensi yang ada pada diri sendiri.

\section{Referensi}

Bangun Darwin, "Hubungan Persepsi Siswa Tentang Perhatian Orang Tua, Kelengkapan Fasilitas Belajar, dan Penggunaan Waktu Belajar di Rumah dengan Prestasi belajar Ekonomi”,(Jurnal Ekonomi dan Pendidikan:Vol 5 No 1, 2008)

Berry Amanda \& Jan H. Van Driel, "Teaching About Teaching Science: Aims, Strategies, and Backgrounds of Science Teacher Educator", (SAGE, 2012).

Diyantini, Sigit-Santosa \& Octaria, Dini, "Pengaruh Prestasi Belajar dan Persepsi Mahasiswa Tentang Kesejahteraan Guru Terhadap Minat Menjadi Guru Pada Mahasiswa Prodi Pendidikan Akuntansi FKIP UNS", (Jurnal Tata Arta,Vol 2 No 2: UNS, 2016)

Djamarah Syaiful Bahri, Strategi Belajar Mengajar, (Jakarta: PT Rineka Cipta, 2006)

Gie, The Liang, Cara Belajar Yang Efisien, (Yogyakarta: Gajah Mada University Press, 2002)

Hurlock Elizabeth, Perkembangan Anak Jilid 2: Alih Bahasa Meitasari Tjandrasa. (Jakarta: Erlangga, 2010)

Jananti Nooriza \& Tarmudji Tarsis,"Pengaruh Kepercayaan Diri, Budaya Lokal dan Pendidikan Agama Terhadap Hasil Belajar Mata Pelajaran Ekonomi Siswa Kelas XI IPS SMA Negeri 1 Demak Tahun Ajaran 2013/2014", (Economic Education Analysis Journal:Universitas Negeri Semarang, 2014) 
Hakim T, Mengatasi Rasa Tidak Percaya Diri, (Jakarta: Puspa Swara, 2005)

Kaymak, Demir-Zeliha\& Mehmet, Baris-Horzum, "Relationship Between Online Learning Readiness and Structure and Interaction of Online Learning Students”, (Edam, 2013)

Muhibbin Syah, Psikologi Belajar. (Jakarta: Rajawali Pers, 2012)

Mulyani Dessy,"Hubungan Kesiapan belajar Siswa Dengan Prestasi Belajar”,(Jurnal Ilmiah Konseling: Vol 2 No 1, 2013)

Ni'mah Fahmi,"Pengaruh Minat Profesi Guru, Locus of Control Internal, Peran Guru pamong, dan Prestasi belajar Terhadap Kesiapan Mahasiswa Menjadi Guru Pada Jurusan Pendidikan Ekonomi Fakultas Ekonomi Universitas Negeri Semarang"(Jurnal Pendidikan Ekonomi,Vol 03: Universitas Negeri Semarang, 2014)

Schnaider Mark, "Do School Facilities Affect Academic Outcomes?", (ERIC, 2002)

Shoemaker A-Candice, "Student Confidence as a Measure of Learning in an Undergraduate Principles of Horticultural Science Course", (Kansas State University, 2010)

Slameto, Belajar dan Faktor-faktor yang Mempengaruhinya. (Jakarta: Rineka Cipta, 2003) 